\title{
光が当たると伸び縮みするフォトクロミック結晶の 開発に世界で初めて成功
}

\section{入江正浩}

光を当てると色が変わることで知られるフォトクロミック分子。今回、立教大学理学部の入江正浩教授らの研究チー ムは、光の照射によって色の変化だけでなく、伸び縮みしたり、曲がったりするフォトクロミック単結晶を世界で初 めて開発した。ナノサイズで物を動かすアクチュエーターとしての応用が期待されるこの成果は、Nature 2007 年 4 月12日号で発表された ${ }^{1}$ 。入江教授に開発の経緯やその意義、今後の展望などについて話を聞いた。

\section{光反応で色が可逆的に变化する有機化合物}

Nature Digest — フォトクロミック分子とはどのようなもので しょうか?

入江 一特定の波長の光を受けることによって、物質の色が可逆 的に変化する現象を「フォトクロミズム」といい、そのような性質 をもつ低分子の有機化合物がフォトクロミック分子です。私たち が20年ほど前に発見し $2 、$ 開発を続けてきた「ジアリールエテン」 とよばれるフォトクロミック分子群では、紫外線を当てると、水砂 糖のような無色の結晶が赤色や青色、黄色、緑色などに変わりま す（図 1)。光エネルギーを吸収して分子中の化学結合の一部が組 みかわり、吸収スペクトルが長波長側、つまり可視光域にシフト するからです。具体的には、中央の3つの二重結合の部分が開環 構造から閉環構造の異性体（6 員環）へと変化するのですが、可 視光を照射すると再び元の開環構造に戻るため、無色になります。 紫外線を受けたときの色がさまざまなのは、分子中の置換基の種 類の違いに依ります。世界中でさまざまなジアリールエテン誘導 体の合成が進められており、今では 300 種以上が知られています。 ND — ほかにどんなフォトクロミック分子があるのですか?

入江 一フォトクロミズム現象を起こす分子は自然界にも存在して います。例えば、植物の光形態形成に働く光受容体フィトクロムに はテトラピロールが、動物では目の光受容体ロドプシンにレチナー ルが含まれています。これらの分子は光を受けて異性化すること によって、生体内に光が入ってきたことを知らせる役割を担ってい るのです。人工物での発見の歴史は古く、すでに1867年には、テ トラセンにおいて最初のフォトクロミズム現象が発見されています。

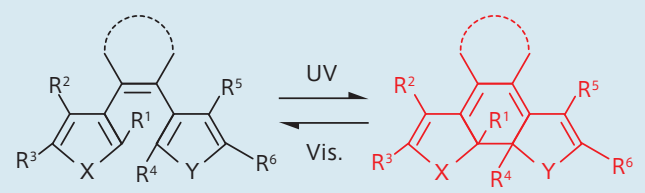

図 1 :ジアリールエテン単結晶の紫外光·可視光照射による着色·脱色と化学式。 結晶だけではく、ジアリールエテンをトルエンなどの有機溶媒に溶かした溶 液や、濾紙に染み込ませたものでも、まったく同じように色が变化する。
その後、20世紀前半には染料合成の際の副産物として、フルギド、 アゾベンゼンやスピロベンソフランなどが偶然に発見されました。 これらは誘導体の合成も容易で、サングラス用の調光レンズとして すでに応用されていますが、不安定で耐久性に乏しく、信頼性に 欠けるという問題があります。しかしジアリールエテンは、熱安定 性（室温で47万年安定）や耐久性（着色·脱色が 1 万回以上可能）、

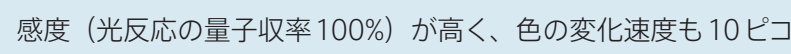
秒以下 $\left(\right.$ ピコは $\left.10^{-12}\right)$ というすぐれた特長をもっています。 ND 一 どのような応用が考えられますか？

入江 一 単一分子光メモリとして使える可能性があります。フォ トクロミズムの反応は、1分子を単位として生じるため、各分子 に独立に光情報を蓄え、取り出すことができると考えられます。 2002 年に私たちは、反応に伴って蛍光強度の変わるジアリール エテンを合成し、分子 1 個 1 個を区別して、オン・オフの書き込 みや読み出し動作の確認に世界で初めて成功しました。これを 用いると原理的には、DVD100万枚分の情報がたった1枚の光 ディスクに入ることになります。「ストレージ技術における高密度 化のロードマップ」によると、現在、1平方インチ当たり数ギガ $\left(10^{9}\right)$ ビットの記録密度が、2030 年には 1 ペタ $\left(10^{15}\right)$ ビット になると予想されています。このような究極の大容量光メモリが、 ジアリールエテンで可能になるかもしれません。

\section{テニスラケットでボールを飛ばすような動きをする結晶} ND 一さらに今回、ジアリールエテンで結晶が変形することを発 見されました。

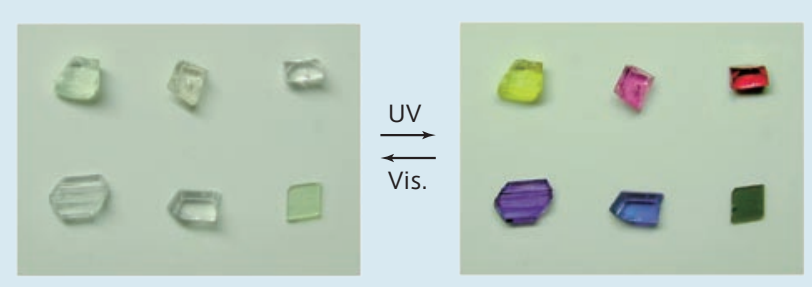
紫外光を当てて屈曲させ、シリカの微粒子 (黒い球、直径 $80 \mu \mathrm{m})$ を飛ばしているようす。棒状結晶の下側部分は 固定されており、そこが支点となって動かない。

(1)

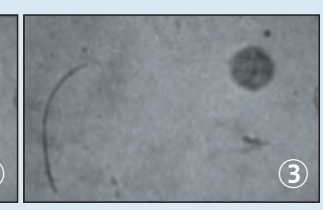




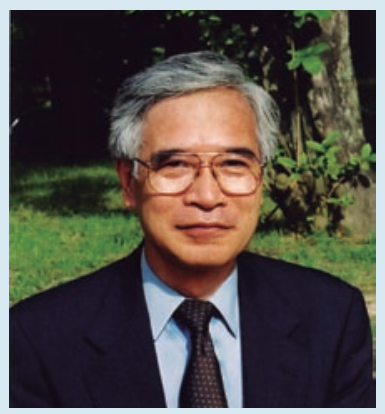

入江正浩（いりえ・まさひろ）／立教大学理学部 化学科教授。九州大学名誉教授。工学博士。専 門は光化学・分子工学。1944年、京都府生ま れ。1966年、京都大学工学部高分子化学科卒業、 1968 年、同大学大学院工学研究科博士課程修了。 同年、北海道大学助手、1978 年大阪大学産業科学 研究所助教授。1988 年、九州大学機能物質科学研 究所教授。1996年、九州大学工学部 (大学院工学 研究院）教授。1997年 2002年、科学技術事業 団戦略的基礎研究推進事業 (CREST)「完全フォト クロミック反応系の構築」プロジェクトリーダーを 務め、2007年4月より現職。

最初の論文は、ESRを用いた溶媒和電子の反応
に関する研究。その後、放射線化学から光化学へ 研究分野を移し、光により溶液物性あるいは固体 物性が可逆的に变化する「光応答性高分子」の基 本概念を提案し、合成高分子が静的構造材料とし てのみならず動的応答材料としても有用であるこ とを初めて示した。1980年代後半に「ジアリール エテン」分子を発見し、現在は、このフォトクロミッ ク分子の顕在、潜在能力の開発と応用展開に努め ている。1988年に高分子学会賞、1993 年に光化 学協会賞、1995年にフランスLVMH財団よりダ ヴィンチ賞、2004年に日本化学会賞、2007年に は向井賞を受賞。2003年にフランス・ボルドー大 学より名誉博士号を授与される。
入江一はい。「フォトメカニカル機能」といって、光に反応して、 微小な結晶全体が伸び縮みしたり、曲がったりするジアリールエ テンを開発することができました。数百 $\mathrm{nm} \sim 0.5 \mathrm{~mm}$ 角程度の 結晶に紫外線を当てると、結晶を構成する分子間の相互作用力が 影響を受け、系全体がより安定な状態へ移行するため、5〜 7\% の割合で縮み、可視光を当てると元の大きさに戻ります。反応速 度は約 $25 \mu$ 秒。長さ約 $300 \mu \mathrm{m}$ の棒状結晶をテニスラケットの ように使い、微小なガラス球を打たせる実験にも成功しました(図 2)。2001 年の時点で、原子間力顕微鏡測定によって結晶表面 が少し動くことがわかっていましたので、結晶をもっと薄く小 さくすれば、系全体が動くのではないかと考えたのです。この研 究の意義は、分子レベルでの変形をマクロな可視レベルでの動き にまで拡大する手法を明らかにしたことにあります。同様のこと が生体では、ATP-ADP変換エネルギーによる筋肉の動きとして 現れますが、人工物での成功例はこれまでありませんでした。

ND — どのようなものに応用できるのですか?

入江一これらの結晶は、光によって歪むことから「光歪素子」と 名づけることができます。電歪素子、つまり電圧を加えると微小に 屈伸する素子はこれまでにも知られていて、MEMS ${ }^{* 1}$ などに広く 利用されていますが、光歪素子の例は少なく、分子結晶としてはこ れが初めてです。光歪素子の大きなメリットは配線を必要とせず、 光を当てるだけで遠隔操作ができることです。極微小領域でメカ二 カルな仕事をする光駆動アクチュエーターとして期待されます。

ND — 今後の方向性をお聞かせください。

入江 一 私は今年の春に九州大学を定年退職して立教大学へ移り、 現在新しい研究室を立ち上げているところです。立教大学では、 今回発表した分子結晶のフォトメカニカル機能に関する研究をさら に深め、ナノレベルでの分子の変形をマクロな世界のメカニカル機 能につなげる仕組みを分子レベルから明らかにしたいと考えていま す。前述のように生体ではいともたやすい「動く」ことが、人工物 では実現していません。これまでもちえなかったこの「動く」とい うメカ二カル機能を合成有機分子材料に与え、それを応用展開する ことがこれからの夢です。また、フォトクロミズム研究の裾野を広 げ、若い研究者の参入を促し、日本のこの研究分野をさらに強く する「特定領域研究」を推進することも考えています。フォトクロ ミズム研究は、単一分子光メモリや光駆動アクチュエーターのほか 単一分子電導スイッチ、光演算素子などの分子素子、機能性光学 材料、光記録、表示材料など、多彩な分野へ発展を続けています。

\section{研究にまつわる 3 つの言葉}

ND 一若い研究者の方々へ、何かメッセージをお願いします。

入江 一私がこれまでの研究生活で気にとめてきた3つの言葉が あります。まずセレンディピティ。予期せぬことから重要な結果 を得ること、あるいはその能力という意味に使われますが、とく に実験を必要とする分野の研究では、必ずこのようなチャンスに めぐり会えます。それを見落とさずに育てることが、創造的な研 究への道を拓くことになります。実はジアリールエテンも、光で 性質を変える高分子材料の合成を研究しているときに偶然に発見 したものなのです。セレンディピティで何かを発見している研究 者はかなり多いと思いますが、それをピックアップしてうまくー 般化するという操作があって、初めて先に進めるのです。その操 作が成功するかどうかは、その人がどれだけの基礎知識をもって いるかに依ります。基礎知識が少ないと、せっかく発見しても小 さくしかまとまりません。

ND 一偶然に発見したものをしっかり取り上げて、大きくでき るかどうかがポイントなのですね。

入江 一次はNIHルールです。NIHはNot Invented Here（ここ で発明されたものではない)、つまりオリジナルな研究しか認めな いことを意味しています。企業はともかく、大学の研究者には大切 なことだと思います。また、米国にはPublish or Perish（論文を 書かない学者は消滅する) という言葉があります。しかし、私が留 学したドイツでは、断片的な研究内容を論文で小出しに書くのでは なく、研究の総体として本を書くことのほうが重要視されます。本 を書くということは、1つの分野を新しく作るということを意味し、 それくらいの高い志をもって仕事をせよということなのです。研究 が職業となったのは、それほど古いことではありません。その職業 に就けた幸せを常に心にとどめて、頑張ってほしいですね。

ND 一ありがとうございました。

聞き手は北原逸美 (Nature Digest のエディター)。

* 1 MEMS

Micro Electro Mechanical Systems（マイクロ電気機械システム）の略でメムス と読む。微小な機械部品、センサー、アクチュエーター、電子回路などを 1 つのシリコン基板上に集積化したデバイスを指す。半導体の微細加工技術を 駆使して作製され、加速度センサーなどの各種センサー、検查測定装置、イ ンクジェットプリンターの微小ノズルなど広く応用されている。

1. Kobatake, S. et al, Nature, 446, 778-781 (2007)

2. Irie, M. et al, J.Org.Chem., 53, 803 (1988)

3. Irie, M. et al, Nature, 420,759-760 (2002)

4. Irie, M. et al, Science, 291, 1769-1772 (2001) 